\title{
New contested borderlands: Senegalese migrants en route to Argentina
}

\author{
Ida Marie Savio Vammen (B)
}

Correspondence: imv@diis.dk Danish Institute for International Studies, Copenhagen, Denmark

\begin{abstract}
This article sheds novel, light on how Senegalese men and women adapt to European border governance by finding new ways to 'look for life' (chercher la vie) in Latin America, as an alternative to the perilous clandestine routes to Europe. The article follows how Senegalese migrants' mobility to Argentina has evolved over the last two decades. It particularly focuses on the migrants' journey to Argentina and explores the migrants' accounts of their experiences en route and compares them to how different intersecting state-driven national and supranational migration policies become entangled in their mobility. By analytically focusing on the changing migration infrastructure and the different forms of friction the migrants encounter and respond to while moving, the article shows how the risk and uncertainty along the journey increasingly mirror the struggles which African migrants face at EUAfrican borderlands, and thus how similar features of global mobility regimes seem to be reproduced along this new route from West Africa to Latin America. In this way the politics and hierarchies of mobility are brought to the fore. Yet the article also points to how migrants find new openings and ways to contest the hindrances that aims to stop them as they move through these newly traversed borderlands.
\end{abstract}

Keywords: Migration policies, Friction, Migrant journeys, Migration infrastructure, Borderlands, Senegal, Argentina

\section{Introduction}

Argentina, Autumn 2013. Lamine's voice sounded both agitated and worried when he hastily briefed his friend Saliou at his small stall in Once, one of Buenos Aires' bustling commercial zones, where many Senegalese street hawkers tried to make a living. After weeks of waiting, Lamine had finally heard from his nephew, Omar, who had left Senegal for Argentina. He expected the call would reassure him that Omar was okay and had arrived safely in Buenos Aires after the long journey overland from Ecuador, through Peru and Bolivia, and across the Argentinean frontier. He had helped to pay the 3 million CFA francs (approximately 4600 euros) for the journey and the migration broker ${ }^{1}$ in Senegal had assured him it would take 2 to 3 weeks. Yet more than a month had passed. Lamine's sister in Senegal kept calling him, asking him for news about her son's destiny, which made him even more anxious. Yet Omar's call had not reassured him but only increased his worries. Omar was stranded at a Peruvian town close to the Bolivian border. He, and the small group of Senegalese migrants whom he had travelled with, had been caught by the Bolivian police and deported back across

(C) The Author(s). 2019 Open Access This article is distributed under the terms of the Creative Commons Attribution 4.0 International License (http://creativecommons.org/licenses/by/4.0/), which permits unrestricted use, distribution, and reproduction in any medium, provided you give appropriate credit to the original author(s) and the source, provide a link to the Creative Commons license, and indicate if changes were made. 
the border, straight into the hands of local Peruvian police officers. Omar had no money and therefore called Lamine to ask for financial assistance, so that he could bribe the police and pay for another migration broker. After the rapid exchange of news, Lamine rushed to wire the money to Peru. Finally, after several more wire transactions, Lamine and his family in Senegal managed to get Omar to Argentina, a journey that ended up taking almost 3 months.

Omar's long and fragmented journey from Senegal to Argentina serves as a point of departure for this article. Not only because it sheds novel light on the recent redirection of Senegalese migration towards Latin America, but especially because it points to how contemporary mobility regimes that 'normalise the movements of some travellers while criminalising and entrapping the ventures of others' (Glick Schiller \& Salazar, 2013 p. 189) mirror each other in their production of migrant illegality (cf. De Genova, 2002). In critical border studies, "borders are no longer at the border" (Vaughan-William, 2008, p. 77) but seen to be everywhere in the sense that they are not just at the outer edges of a state, but proliferate throughout society (Rumford, 2008 , p. 2). Since borders are now everywhere, for migrants they are not only an obstacle which is difficult to surmount, but something that they repeatedly run up against (Balibar, 2002, p. 82). Following this assumption, the article seeks to liberate the notion of borders from geographical bias and instead explore migrant journeys to Argentina as sites of struggle where, in the wake of EU externalization polices and the openings of new opportunities in Latin America, Senegalese migrants redirect to Argentina. I do this by highlighting how new forms of precarious mobility over time are produced along emergent routes to Argentina, but also by drawing attention to how migrants like Omar and their families in Senegal continuously contest and circumvent the barriers set up to hinder their mobility in their search for a better life.

The article is based on 9 months of ethnographic multi-sited fieldwork among male and female Senegalese migrants in Buenos Aires working in the large informal economy of street hawking, but also in Senegal (in three periods between 2012 and 2015). My interlocutors consisted of 55 migrants, and from this group I formed a close relationship with a smaller group of 15 people, whose lives I followed over an extended period. Through my conversations with the migrants and their families in Senegal, interviews with migration brokers and migration authorities, I learned how their mobility from the outset was shaped by shifting state-driven politics of mobility, national and supranational laws, that across different geopolitical spaces produced intersecting barriers and friction in their lives but also, as we shall see, new openings. In this article I focus on the migrants' narratives of their journeys to Argentina at different points in time to bring to the fore the lived experience of migration policies. Despite the different routes and temporalities, these journeys were marked by illegality and clandestine migration. When juxtaposing the different narratives, they illuminate how shifts in both European and Latin American migration policies from the 1990s onwards have altered the journeys for Senegalese migrants, both creating new opportunities but also increasingly making them longer and more perilous.

To ensure that my research will not put the people I have worked with, or other migrants journeying on the same paths at risk, I have in this article, blurred the identities of my interlocutors and the specific locations of the routes and border crossings. Migrants have, as Sharam Khosravi has emphasised, the 'fundamental right to opacity' 
(Khosravi, 2018, p. 3). While blurring some aspects of my work, at the same time, I want to highlight the many obstacles and different forms of systemic violence that contemporary mobility regimes produce.

\section{Analysing friction along migration journeys}

Migration studies has traditionally focused mostly on either the drivers of migration in the sending of communities, or the outcomes of migration; particularly migrants' societal incorporation and exclusion. Yet recent scholarship aims to go beyond such sedentary perspectives and instead draw attention to the process and the production of (im)mobility, as reflected in much of the recent ethnographic literature on African migrants' journeys to Europe. This literature highlights that African migrants' journeys have not been blocked, as intended, by European policies and enhanced border control. Instead these measures have only made the journeys increasingly turbulent and longer, in both duration and distance, whilst further disconnecting the migrants from the promises of globalisation (Andersson, 2014; Bredeloup \& Pliez, 2005; Graw \& Schielke, 2012; Jackson, 2013; Kleist \& Thorsen, 2016; Lucht, 2012; Schapendonk \& Steel, 2014; Vigh, 2009). To avoid the surveillance and policed zones along the border with Europe, the migrants' trajectories keep changing and now run along less controlled and more dangerous routes across potentially lethal paths in the desert and over the sea or the mountains, often using smuggling networks to reach their destination (Andersson, 2014; Collyer, 2010; Lucht, 2012; Richter, 2016). ${ }^{2}$ Some of these scholars have used a more theoretically grounded lens that compares contemporary clandestine migrant journeys to Europe with those to North America (Mainwaring \& Brigden 2016). Collyer (2010) for example argues that a significant feature of global migration governance today is the long, dangerous, fragmented journey. This feature is global because it not only affects African migrants, but a large part of the world's population which cannot access legal forms of mobility. Like the thousands of unwanted migrants from Latin American countries who, especially after 9/11, experienced the securitisation of the US-Mexico border (Boehm, 2012; Coutin, 2003; De Genova, 2002). However, less attention has been paid to the uncertain political landscapes and shifting contexts migrants find themselves in and how migrants finds ways to circumvent states' monopoly on defining legitimate movement (Casas-Cortes et al., 2015; Schapendonk, Van Liempt, Schwarz, \& Steel, 2018).

This article draws on and contributes to this recent literature in two ways: Firstly, by redirecting the gaze to Latin America and focusing on new ways in which African mobility is constrained. By shifting our focus away from South-North dynamics to new borderlands and South-South migrant trajectories, the article gives ethnographic context to the pervasive nature of borders linking EU-externalisation efforts in West Africa with the new, emerging forms of migration to Latin America. Secondly, by analytically drawing attention to friction as a concept that can help us unravel the shifting, complex landscapes of different multiscale forms of border politics that, on the one hand, imbues the migrants' way of navigating in the world, and on the other, creates new forms of resistance from below (cf. Cresswell, 2010; 2014; Tsing, 2005). Friction makes it possible to analytically unpack the politics of mobility that have shaped this redirection, by focusing on what happens when migrants are stopped - stopped by, for 
example, enhanced border control and visa regulations at the border, but also far away from it. Tim Cresswell argues that 'friction' is always 'lived and felt' in social and political contexts, and in the 'stickiness of space and place' and is the result of the ongoing struggles over the governance of mobility (Cresswell, 2014, p. 114). Yet following Tsing, friction calls attention to the way in which heterogeneous and unequal encounters can 'lead to new arrangements of culture and power' (Tsing, 2005, p. 5). Friction not only stops things and people, but also creates a by-product: heat. In this article this is shown as new forms of social heat, occurring when people are stopped by different forces in their environment, yet try to find different tactics of resistance to keep moving.

To 'find' the shifting politics of mobility and the various forms of friction, it is useful to take a closer look at the particular channeling of mobility and the migration infrastructures that, in different ways, take on this function. Xiang and Lindquist (2014) define migration infrastructure as 'the systematically interlinked technologies, institutions and actors that facilitate and condition mobility' comprised of 'the commercial (recruitment intermediaries), the regulatory (state apparatus and procedures for documentation, licensing, training and other purposes), the technological (communication and transport), the humanitarian (NGOs and international organizations), and the social (migrant networks)' (2014, p. 124). By analysing the migration infrastructures, we not only capture how migrants move but also how they are increasingly moved by others, in different ways, with distinct modus operandi. Drawing inspiration from their work, I find it analytically useful to especially explore how such infrastructures produce mobility through channelling, facilitating the redirection of Senegalese migrants to Argentina. In other words, I bring friction to the centre of the analysis by exploring how these infrastructures also limit where the migrants go and become blocked.

The article starts by linking the developments at the EU-African borderlands to the emergence of Senegalese migration to Argentina. I then, based on two migrants' narratives of their journeys, point to how migration infrastructures have adapted and changed over the course of two decades, highlighting how the journey has been altered by different forms of restrictive and liberal migration governance. In closing this article, I discuss the implications of this development and what they tell us about migrants' position in the global order in conjunction with the fragmented and potentially lethal trajectories of African men and women on their way to Europe.

\section{Closing borders and the emergence of Senegalese migration to Argentina}

For decades, migration within West Africa and to Europe has reconfigured Senegalese society, family life and the landscape of many urban areas and villages, creating visible testimonies of what one can become and amass from successful migration (Bredeloup, 2013; Nyamnjoh, 2010; Riccio, 2001, 2008; Sinatti, 2009). But within the last few decades the West African region has become the scene for a wide range of European externalization policy interventions with the purpose of keeping potential migrants out, shaping the migration infrastructure from West Africa to Europe. In the past, most African migrants travelled through the Maghreb countries on their way to Europe. Yet, when Europe opened its internal borders with the creation of the Schengen area in 1990, the Spanish enclaves of Ceuta and Melilla became the union's only terrestrial borders in Africa and the gateway to Europe. Since the 2000s, in particular, Spain 
together with the European Union, intensified its efforts to control and patrol its borders, in collaboration with North African countries (Andersson, 2014, p. 21). As the number of migrants trying to cross grew, so did the height of the fences and the number of sensors and cameras that could detect unwanted migrants (Andersson, 2014, p. 155). These initiatives were largely funded by the EU to curb 'illegal' African migration, yet they had the effect of pushing the migrants towards more dangerous and fragmented journeys such as those to the Canary Islands, creating the so-called 'boat crisis' in 2006 (Andersson, 2014).

Simultaneous to the influx of West African migrants to the shores of the Spanish Canary Islands in the mid-2000s, although in much smaller numbers, Argentina emerged as a destination for West African migrants, in particular from Senegal, along with other new destinations in Asia, the Middle East and Latin America (see, for example, Bertoncello \& Bredeloup, 2009; Haugen, 2012; Maffia, 2010; Pelican \& Tatah, 2009; Schans, 2012; Suter, 2017; Zubrzycki, 2009). The dislocation of Europe as the centre, the acceleration and spatial diversification of African migration beyond former colonial links seemed to be partly driven by shifts in Western migration governance (Flahaux \& de Haas, 2016) but also new opportunities. When the opportunities to enter Europe and North America lessened, it seemed as though some migrants' hopes for a better future were redirected towards new destinations and emerging economies while others still tried to go to Europe or the US. These new destinations were, in many cases, more palatable alternatives than their preferred destinations, but can also be seen as an example of how Senegalese migrants sought new opportunities and relied on alternative migration infrastructures but also changed their perceptions of Europe, especially after the economic recession (De Clerck, 2015; Hernández-Carretero, 2016). This was the case for my interlocutors. Their first thought was to go to Europe, yet when trying to make plans for this journey, they and families found out that 'Europe was finished'. Family members already living in Europe, migration brokers in Senegal, and the news media portrayed, at the time, a closing Europe and an uncertain and potential lethal route that they were not willing to risk taking. But the shift to Latin America also has to be connected to the region's relatively liberal migratory policies and vast, porous sea and land borders, as we shall see below.

One of the few authors that has explored in more ethnographic detail, how the connection between West Africa and Latin America was established, is Minvielle (2010, 2015), who points out that in 1990, Malian migrants were already leading the way to establish the new African-South American connection. In Libya, these pioneer migrants obtained a visa from the Brazilian embassy; initially intending to use Latin America as a stop on their quest to reach the US. However, before they could go any further, they had to work to regain some capital. Some stayed in Brazil while others moved from Brazil to Argentina, where they could use the skills they had gained from working in the construction sector in Libya in the booming neoliberal Argentine economy of the 1990s. This was a time when Argentina's economy temporarily recovered from its economic decline during the military dictatorship (from 1976 to 1983) and the following periods of hyperinflation that pushed President Raúl Alfonsín to resign in 1989. In 1991, under the new Argentinian President, Carlos Saúl Menem, the peso was pegged to the US dollar as a remedy against hyperinflation. This created a favourable conversion rate for the new group of migrants. According to Minvielle (2010), the flow 
of Malian migrants never really picked up in Argentina whereas that of the Senegalese did, although slowly and in small numbers. Other African migrants from Ghana, Cameroon, Sierra Leone, Liberia and Nigeria followed from the 1990s (Zubrzycki, 2012). In the 2001 national census, 1883 Africa-born nationals declared that they lived in Argentina. Close to 10 years later, the 2010 census showed that this number had increased to 2738, yet when compared with the number of asylum applications from African nationals, the number is thought to be much higher (Freier, 2012; Zubrzycki, 2012). Data shows a clear increase in the number of Senegalese migrants in the county. From 2011 to 2015, 4747 persons obtained a residence permit in Argentina, 97.7\% of which were male. ${ }^{3}$ Some of them (1391 persons) obtained these through a short regularisation program in 2013 (see Vammen, 2016). Yet the actual number of Senegalese migrants in the country is most likely much higher since many live undocumented lives in the country.

Minvielle also draws a link between migrants' increasing interest in Argentina and the commercial side of the migration infrastructure. Local communities in the groundnut basin could see how migrants who temporarily returned were able to invest in property and weddings, and the flow increased due to the growing industry run by migration brokers who 'facilitated and recruited aspiring migrants in Dakar, Thies, Diourbel and Touba, Mbour and Kaolack' (Minvielle, 2015, p. 22), like they do today. This industry thrived through the brokers' connections to the various embassies in Dakar, travel logistics and social contacts that could facilitate the passage from Brazil to Argentina. It also provided the capital needed to fulfil certain visa requirements. According to Minvielle (2015), these recruiters often relied on marabouts (religious leaders), who gave them access to their disciples. To inspire the migrants, these industry actors sold Argentina as 'une terre de "l'Amérique", a door to an el dorado where Argentina or Brazil were just one lucrative stop on the way to the US.

\section{Journeying to Brazil and Argentina with little friction}

The majority of the migrants I met in Argentina between 2012 and 2015 had arrived after 2007, and had entered the country in a number of ways. Unlike Minvielle's findings, only one of my interlocutors emphasised that Argentina was a stopover on his way to the US. After Europe, Argentina was the preferred 'destination' of my interlocutors. Yet the 'destination' as such was never fixed to a specific national territory as they were simultaneously attentive to new developments and loopholes, especially when times were difficult in Argentina. Travelling to Argentina was seen as a safer option than attempting to take potentially lethal clandestine routes, only to end up in Europe's economically difficult and hostile climate.

Yet in order to get to Argentina, the migrants needed a visa to board an international flight. Argentina previously had diplomatic representation in Africa, however, when the country's economy crashed in 2001, several foreign embassies closed, including the embassy in Dakar. This meant that, to get an Argentinian visa, the migrant, or in most cases the migration broker, had to go through either the Argentinian embassy in Abuja (Nigeria) or Rabat (Morocco). Yet the most popular route was through Brazil, as a range of international airlines flew from Dakar to Brazil, with a stopover in Madrid or Lisbon. With a visa for Brazil, they left Senegal where upon arrival, they embarked on 
the almost $2000 \mathrm{~km}$ long journey south to the Argentinian border. Despite the irregular border crossing into Argentina, the migrants whom I talked to who had used this route did not have any major difficulties with police at the time, either in Brazil or at the border. The following account of Cheike's journey is a telling example of the long, yet relatively smooth nature of migrants' journeys before efforts to curb the flow were introduced, which redirected the migrants towards longer and more dangerous paths, increasingly involving migration brokers.

\section{Cheike: 'I thought that Mercosur would be like Schengen'}

Cheike had given up his studies in Dakar to follow his sister-in-law to Argentina. He described his journey as follows:

When I decided to go in 2010 there were no diplomatic relations between Senegal and Argentina, so I could not get a visa to go directly. Fortunately, Brazil has an embassy in Dakar and in that way I got a Brazilian tourist visa. I flew to Rio de Janeiro with a stopover in Lisbon. In Brazil, I took a bus to São Paulo before changing onto another bus that could take me to the Brazilian side of the border, where I could cross into Argentina. I arrived at night, at the border, and a local guy offered to take me across in his car. He told me he knew the border well. He was one of these people who helped migrants across; he was just there at the bus terminal and said that he could help me for 300 pesos. That was how I got across the border without any trouble. El muchacho [the young guy] picked me up in his car, together with his wife and children, and they drove me over the bridge to the bus terminal on the Argentinian side. From there I took a bus and arrived in Buenos Aires in the morning. I called my sister-in-law and gave a taxi driver the phone, so that he could get directions to her house. To be honest, I did not have any difficulties. I came legally to Brazil and then just crossed the border. I thought that Mercosur [the Southern Common Market] would be like Schengen in Europe, where you could move freely... [Cheike laughs]. I learned this at secondary school, but it is completely different. The free movement is only for Mercosur citizens and not foreigners. Once in Argentina, I talked to the other Senegalese migrants. They sent me to Comision Nacional para Refugiados to ask for la Precaria ${ }^{4}$ so I could move freely within the country and at least have some kind of papers. I went to the interview and told them I had come to work and study. I did not lie, and they gave me la Precaria even though they knew from the outset that I was not a refugee.

Most of my interlocutors traveled from Senegal through Brazil to Argentina directly, like Cheike. Yet it was not uncommon to meet migrants who had stayed in Brazil for a few months before moving to Argentina. Brazil was, at the time, the seventh-largest economy in the world and an attractive option for Senegalese migrants. The country experienced high growth rates and became one of the BRIC darlings and was perceived as an engine for global economic growth, especially after the economic downturn in Western economies in the late 2000s. When I was in Dakar in early 2014, I was told by several people 'that everybody talked about Brazil'. For the migrants, the idea of Brazil as an attractive destination was further fuelled when it was announced that the country would host the 2014 FIFA World Cup and the 2016 Olympic Games. At the time, the 
country had a quite liberal migration policy, facilitating legal stay for migrants who overstayed their visa, and it was not uncommon for the migrants to circulate between Argentina and Brazil, depending on the different opportunities arising in the two countries (Chevalier-Beaumel \& Morales, 2012). But, when migrants like Cheike had relatives or friends living in Argentina, they often travelled directly there without first trying their luck in Brazil. In short, the choice of destination not only depended on the regulatory framework of the migration infrastructure, but also largely depended on pre-established social networks, as well as the imaginaries and hope the migrants connected to the specific destinations (Vammen, 2016, 2018).

At the time of Cheike's journey to Argentina there were not many measures in place to stop irregular migration to Argentina. The border was porous but, at times, the control intensified, forcing the groups of migrants traveling together to use local middlemen to take them across the River Uruguay at night. When the border-crossing developed in this way, it was a matter of great concern for the migrants, especially because some could not swim or did not know what could be hiding in the dark river. For instance, Binta, an older Senegalese woman, told me how terrified she was when she had to go for a long hike at night, in order to cross the river. The water started to rise up to her waist, and she slipped and cut her foot in the mud. 'If I had known that I would have to travel like this, I would never have left Senegal', she claimed, pointing to the fact that my interlocutors often did not know about the specific risks en route beforehand.

Once the migrants arrived on the Argentinian side of the border, they were able to continue on buses from the tourist centres in the north of Argentina. Although Mercosur citizens can move freely within the Mercosur zone, as Cheike observed, the Brazilian visa did not mean that the same rules applied to non-Mercosur migrants. Non-Mercosur migrants have to navigate the changing economic and political landscape, using irregular pathways along the border zones of Mercosur in order to enter Argentina. This distinction between Mercosur and non-Mercosur migrants was one of the major challenges for migrants trying to regulate their stay in Argentina and thereby transcend the 'illegality' that marked them as they crossed the Argentinian border (see Vammen, 2016). Some, like Cheike, choose to apply for asylum as a way of obtaining some sort of documentation that will, at least, grant them certain rights while their case is pending. These cases move slowly through the Argentinian bureaucratic system - a process that can take up to 2 years, at the end of which most of them are denied asylum. Afterword's, those who did not manage to be part of the regularization program in 2013 remained undocumented in the country, as Argentina at the time did not effectuate deportations. ${ }^{5}$ Nevertheless, the long but fairly unproblematic journey to Argentina was put on hold. From my interviews with Argentinian migration authorities as well as with NGOs, it appears that, towards the end of the 2000s, the Argentinian state started to become aware of the influx of Senegalese migrants, especially given the rising number of asylum applications. At this point, Argentina put pressure on the Brazilian authorities to stop authorising visas, mirroring European forms of migration management. Apparently, the cause of the high number of visas was that some migration brokers were "too closely connected" to the Brazilian embassy in Dakar. In short, the regulatory reduction of the legal infrastructure which, until then, had primarily been used, became blocked due to diplomatic pressure. However, this blockage did not 
stop the migrants from going to Argentina. Around that time, Ecuador became the new gateway for Senegalese migrants on their way to Argentina although some of them also managed to enter through Bolivia. In short, the friction produced a shift in the infrastructure that facilitated and channelled the migrants mobility towards new openings but also towards much longer and challenging routes across the Andean borderlands.

\section{New fragmented journeys from Ecuador to Argentina}

This particular redirection to Ecuador has to be viewed in the light of the country's liberal visa policies that opened up a new regulatory infrastructure for the migrants and brokers. On 20 June 2008, Ecuador's President Rafael Correa agreed to make the country a universal zone of visa freedom, lifting all requirements for obtaining a 90-day visa to serve a populist national agenda and uphold his image as a defender of human and migrant rights (Freier, 2013: p. 1). The unintended consequence was an increase in irregular migration, not only from African countries, but also from Asia and the Caribbean (Freier, 2013). ${ }^{6}$ A national opposition formed in Ecuador against the new policy, raising concerns about the security of the new South-South flows and of countries within and beyond the region which pressured President Correa to take action diplomatically. Six months later, in December 2008, the requirements were reintroduced for Chinese citizens and, in September 2010, for nationals from Afghanistan, Bangladesh, Eritrea, Ethiopia, Nepal, Pakistan and Somalia. On 16 November 2015, Senegalese migrants were included in similar visa requirements, a point I will return to in the conclusion. The migrants I met in Buenos Aires that had not had the opportunity to go through Brazil, had instead used this window of opportunity. Yet their narratives of the journey clearly show that the redirection was not without consequences, but was associated with new forms of friction and immobility as they were stopped along the journey. Increasingly, they had to depend on brokers who could not only guide them across the Argentinian border, as before, but also through large parts of the close to 4000-kmlong journey across the Andean region from Ecuador through Peru and Bolivia to the Argentinian border.

The authorities and local news outlets in Ecuador, Peru and Bolivia similarly started to document the new migratory flows. Looking at the available official statistics of arrivals in Ecuador it seems that, until 2011, only very few Senegalese migrants entered Latin America through Ecuador. Although such numbers cannot tell us about the destination of the migrants nor their motives for coming to Ecuador, they still indicate a rapid increase in the influx of migrants over a short period of time. In 2011 only 21 Senegalese migrants arrived in Ecuador. ${ }^{7}$ The year after, the number rose to 247 and then increased substantially to 1383 in 2013 and 1828 in 2014. The vast majority were males (in 2011, only four of the 21 migrants recorded were female and, in 2014, only 34 were female). With this increase, the local media in Ecuador, Peru, and Bolivia started to notice the changes and began reporting police detentions of Senegalese migrants in transit and the deportation of migrants, not back to Senegal, but back to the country which they entered legally - Ecuador. For example, in the spring of 2013, the authorities in Bolivia looked into the arrival of 250 Senegalese migrants, all with 90-day visas for Ecuador but showing no sign of entering or leaving Peru. ${ }^{8}$ There were also news reports and stories about smaller groups of Senegalese migrants being caught 
hiding in trucks, in apartments in the smaller towns along the route, or close to the border, waiting to cross over to Argentina and Brazil. The police investigated many of these cases as trafficking of persons and linked them to the rise of a new form of organised crime and gangs.

Through Badou's story of his journey, I will discuss the implications of the increasing forms of friction the migrants experienced when they rerouted their journeys, mainly from Brazil to Ecuador but also sometimes to Bolivia. In this way, I will illustrate how African men and women yet again had to make new, fragmented, journeys and enter precarious situations where people running out money found themselves stranded en route - but this time on Latin American soil. However the migrants' stories about these intensified forms of friction also illuminate how despite their struggles, they found ways to overcome the hindrances that aimed to render them immobile.

\section{Badou's story: a perilous journey along the Andean route}

Badou travelled to Argentina in 2014 and had been in the country for just 6 months when I met him. He was one of the migrants who, like Omar whom we met at the beginning of this article, had used Ecuador as a gateway to Argentina. Badou was from Dakar and he never thought he would have to migrate, even though his older sister would suggest it from time to time. He sold used car parts and motorcycles, and had a good business. But at one point business decreased, and when Badou's sister once again asked if he would consider migrating, he thought it might be an opportunity for a fresh start:

'I had a bit of money saved, and my mother helped me to pay for the travel and gave me the money I needed for the trip. At first I thought about going to Europe - I have family in France and Spain - but I would have had to wait to sort out the many requirements for a visa and I didn't have the patience. I was like a balloon ready to explode so I talked to a friend who had mentioned Argentina. He said that things were good and that there was work. I didn't know anything about Argentina, and I didn't know anybody - all I knew was that it was another world and a new beginning for me. I was leaving to seek something better.'

Through his mother, Badou got in contact with a migration broker that could facilitate his journey to Argentina. The broker explained that Badou would fly from Senegal to Ecuador and from there, travel overland, to Argentina for 3 to 4 days. When Badou arrived at Guayaquil Airport in Ecuador, after a stopover in Spain, he thought he was almost there. The idea of a simple and fast journey in retrospect made him laugh, and comment: 'Now I feel like a fool but how could I have known?' At the airport he tried to call a number the migration broker in Senegal had given him in advance, but nobody answered the phone and Badou had to find his own way to the hotel. At the hotel, Badou rested a bit and later went out to buy food and a mobile phone. Initially he was afraid that he would encounter the police and they would ask for his papers, but the man in the hotel reassured him that he could walk around without any hassle, because he had visa. With his new phone, he called the migration broker in Senegal, because he started to get the feeling that his journey might not be as smooth as he had initially 
envisioned. The following is his a condensed version of his account of his long and fragmented journey across the Andean borderlands:

'He told me that I should wait and a guy would call me and tell me what to do. That reassured me a bit. I waited two hours before another guy called me from Senegal. I thought it would be a man in Ecuador, but he was in Senegal. He told me that around 3pm a guy from Ecuador would come and pick me up. When he came, we took a taxi together to the bus terminal and got on a bus. After some time, we got off in a place where he had left his car, and we drove to a town close to the [Peruvian] border, where we stayed for two days in a hotel and ate good food and relaxed. We were waiting for a guy who would take me to the border on foot and by motorbike, because it was better to travel without the lights of a car off the highway.

We started off on foot and then we had to cross a river. I got very cold. On the other side of the border, we went to a horrible house nearby. People there were acting very strangely, looking at me like they'd never seen a black person before and wanting to touch me. I tried to comfort myself, thinking that they were people just like me so I shouldn't freak out or make trouble. I just had to wait, but not trust anybody. After some time, a guy brought some motorbikes and we went to a house that was in a bit better condition, but there were other problems. There were two other Senegalese guys waiting in the house. I was very relieved that finally there were people I could talk to. We spent almost a week, in a room, in the house. We could only go outside when we needed to go to the toilet. The people there didn't care about us, and they didn't bring us food regularly. And when they did, it would just be a little bit of bread or a coffee that we could share. Normally I can go without food for a day or two, but we waited three days for a proper meal and I got very weak and started to vomit, and spent most of the time sleeping.

After a week we were put on a bus. But the other Senegalese guy didn't have enough money, so we had to leave him behind; as we set off, he looked at us with big frightened eyes. I gave him a bit of the money I had left, and the other guy did the same, but it was not enough for him to come with us. We paid 400 USD. So he had to wait for somebody in Senegal to send the money, before he could continue. The two of us got on the bus. But we did not sit down in the bus like normal passengers. Behind the bus driver was a small box. Like animals, we had to get inside and kneel down on the floor. There was just enough space. It was very hard to sit like that for almost four hours.

'Were you not scared?'

No I had started to not care anymore. It was a feeling I did not know. It had started in the house, I was so tired. I didn't care if I arrived or if we had to be sent back. After some time, the driver told us that we could come out and sit down. The other people on the bus just looked strangely at us when we crawled out, but I didn't care. Close to the Bolivian border, we stayed in a small town at first - I can't remember the name - and from there they took us to a hotel for four days. It was very cold and the guy we had left behind did not turn up. 
From there we crossed the border to Bolivia and went to La Paz. The border was not the problem - we had a guy traveling with us - but, on the way to there, we ran into problems. It was dark, and we had to walk in the mountains; it was very dangerous, hard and cold, and we had to climb up and down. People fell, and we were exhausted. It was very dangerous and we had no water - nothing! Close to La Paz there were more people. We waited a day and, at night, the third guy, whom we had had to leave behind, arrived, along with one more Senegalese guy. In the morning we were supposed to take a bus to Argentina, but when we came down from the apartment, we ran directly into the police. They asked for our papers. First, I told the others we should not give them anything, but we could see that there was no other option. They looked at them and saw we had a visa only for Ecuador, and then told us to come to the police station with them; the Bolivian guy that had helped us was quick to disappear.

At the police station, Badou and the other migrants managed to bribe the police, but what they initially had to offer was not enough, and they had to call their families in Senegal to ask them to wire more money.

The police took us to the bus station; we could not believe it. 'Yalla Baax na' - God is good. Close to the Argentinian border, we stayed at a guy's house for a few hours to eat and take a shower, before he took us across in his car. On the Argentinian side, the police stopped our car and told us all to step out of it. They asked for our papers and we waited. One of the guys wanted to run; our journey was almost at an end. We had just crossed over into Argentina. But we all told him not to. The police said: 'Hey you are from Senegal'. Then I didn't know that the people in Argentina saw people from Senegal as being peaceful and never causing problems. So they just let us go, so that we could take a bus to Buenos Aires, even though we did not have a visa.

When Badou arrived in Buenos Aires, he called his mother - the journey had taken 29 days and she had been very worried. He told her he was okay, and that he was now going to work and start making a living in Argentina. But, the friction along the migratory trajectory did not cease upon arrival in Buenos Aires. Badou's everyday life and presence in the city was, as for most of the migrants, challenged by urban forms of governance and policing which obstructed his livelihood possibilities (see Vammen, 2018).

Badou's story is a telling example of what happened when the legal infrastructure that channelled the migrants through Brazil on their way to Argentina was blocked. Migration to Argentina was not stopped. Knowledge about Argentina as a promising destination for migration still diffused from social networks and migration brokers in Senegal, and instead the migration infrastructure rerouted and adapted to Ecuador's regulatory opening. For the migrants, their journey became twice as long and much more perilous. New forms of friction across newly traversed borderlands emerged. The migrants' journey became more fragmented, precarious and costly than the previous route from Brazil. The migrants were pushed through the mountains along isolated pathways, across rivers or hidden away in trucks. As soon as they crossed Ecuador's border with Peru, the mark of illegality made them much more dependent on 
intermediaries in the form of both migration brokers and local police officers who demanded more money. The migrants told me that they had strong suspicions that the people who facilitated the journey worked in close cooperation with the local police. As in Badou's story, the police typically arrived in ways that suggested that they knew about the migrants' travel plans and location, and at times the police would, after being paid, directly facilitate the migrants' onwards journey. In short both the commercial and social infrastructures adapted and became increasingly important but were at the same time co-producing precarious mobility. For Badou, travelling with other Senegalese migrants made him less anxious, and together they found ways to negotiate and overcome the hindrances that threatened to reroute them and prevent them from arriving in Argentina.

Badou, like most of the migrants I met, knew only a few details in advance about this last leg of the journey. Some only found out that they would have to travel via Ecuador when, in Léopold Sédar Senghor International Airport, they read their ticket and learnt that they were not flying directly to Argentina. Many did not have sufficient capital to bribe the different border actors en route and, like Omar, had to depend on their family members to transfer more money so they could keep going. The uncertain waiting, and back-and-forth movement across unknown and at times dangerous territories, the encounters with the local police, and their dependence on different groups of migration brokers who were often not genuinely concerned with the migrants' well-being, created fear and disillusionment, to the point where apathy became the predominant emotion, as Badou also emphasises in his narrative. In summary, Senegalese migrants yet again had to journey along extensive borderlands and fragmented routes to reach their 'destination'.

\section{Conclusion: border homologies}

By linking the recent redirection of Senegalese migrants to Argentina with the barriers set up to stop African migrants at the EU-African borders, this article shows how 'unequal encounters' produce new South-South connections (cf. Tsing, 2005). Since the mid-2000s, migrants who have no access to safe and legal ways to enter the EU and who can find the means to fund the costly journey to Latin America have redirected their hope and found their way to Argentina. I have shown how the journey has evolved over the past two decades. From being a long but fairly unproblematic route from Senegal through Brazil to Argentina, the journey, especially since the late 2000s, has become increasingly difficult and perilous as a result of the Argentinian government's efforts to curb the increasing arrivals of Senegalese migrants, but also liberal openings in Ecuador. A shift that has compelled migrants to travel on the margins 'like animals', cramped in hidden spaces and hiding from the local authorities, who want to enforce migration management or just to profit and make a living from the new flow of migrants in transit.

The article's conceptual attention to infrastructure and friction has highlighted the continuous struggle over the organisation of geopolitical spaces produced by both shifting mobility regimes and the migrants contestation of them (cf. Lefebvre, 1998). Such spaces have histories that the migrants encounter en route, affecting and orienting their bodies in particular ways at different instants of the journey. At the same time, the attention to friction and the way migrants are channelled does not only show the shifts and contrasts between geopolitical spaces at different points in time but also the homology between 
them. In other words, the relational similarities in the way friction created by the different mobility regimes produce fragmented journeys, vulnerability and risk for the migrants that contest the emerging borderlands. By challenging the established boundaries and the organisation and governance of foreign powers, migrants do not passively accept their position. Instead, they try to manipulate the mobility barriers they meet to their advantage. By examining how mobility is felt by the people we study, the homologous yet different politics of mobility come to the fore, as people's experiences are likely to indicate their position in the global mobility hierarchy (cf. Cresswell, 2010). For those at the top, the journey is most often smooth and voluntary while, for those at the bottom, like Omar and Badou, it is associated with uncertainty, involuntary immobility or being forced to move from places where they would rather stay (Bauman, 2004).

The articles shows that, despite the migrants' efforts to avoid European mobility regimes that produce potentially lethal trajectories at the Euro-African borders and increasing deportation regimes, they are facing similar features of global migration governance creating new hardships along the trails of this recent South-South flow. With Ecuador's new visa restrictions for Senegalese nationals and Argentina's recent shift away from its former progressive migration laws toward initiatives that will accelerate deportations and curb access to the country (Grimson, 2017), the routes seem to be shifting yet again. On May 20, 2018, 27 people from West Africa, including Senegal, were rescued off the coast of northern Brazil. The boat had been at sea for 4 weeks. ${ }^{9}$ In summary, although shifting mobility regimes try to curb migrants' mobility, new routes emerge. But as this article has highlighted, the marginalisation of the migrant subject and the risks and abjection that come with traveling on the margins of the global mobility hierarchy seem to journey with them, despite their efforts to resist.

\section{Endnotes}

${ }^{1}$ In this article I see migration brokers as part of the parcel of actors who facilitate migrants' mobility in legal or illegal ways through a range of services (GammeltoftHansen \& Sørensen, 2013).

${ }^{2}$ See also the two recent anthologies by Streiff-Fénart and Kabwe-Segatti (2012) and Triulzi and McKenzie (2013).

${ }^{3}$ Informe Migratorio Sudamericano $\mathrm{N}^{\circ} 2$ Año 2017. RECIENTES TENDENCIAS MIGRATORIAS EXTRA E INTRA-REGIONALES Y EXTRA-CONTINENTALES EN AMÉRICA DE SUR. https://robuenosaires.iom.int/sites/default/files/Documentos\%20 PDFs/Recientes_tendencias_migratorias_extra_e_intra_regionales_y_extra_continentales_en_america_del_sur_es.pdf (accessed 3 August 2018)

${ }^{4}$ Once the Argentinian authorities open an asylum case, the applicant is given a legal document, la Precaria, which is valid while the case is pending. With this document the applicant can work, study and access the public Argentinian health system free of charge.

${ }^{5}$ From 2012 to 2016, 2174 Senegalese migrants applied for asylum. ESTADÍSTICAS Período 2012-2016, Comisión National Para Los Refugados: http://www.migraciones. gov.ar/conare/pdf/estadisticas_conare.pdf (accessed 2 august 2018).

${ }^{6}$ Prior to the visa freedom, Ecuador had long been a transit country for migrants wanting to go to the US or Europe, often with the help of smugglers (the so-called 
coyotes), due to the country's porous borders and geographical proximity to Central America (Freier, 2013: 16)

${ }^{7}$ All numbers come from Ecuadorian government statistics (http://www.ecuadorencifras.gob.ec/entrada-y-salidas-internacionales/) (accessed 22 March 2016); numbers are only available until 2014.

${ }^{8 ،}$ Migración investiga arribo de 250 senegaleses a Bolivia no descartan trata y tráfico':http://hoybolivia.com/Noticia.php?IdNoticia=79258\&fb_ref=Default (accessed 21 November 2013).

${ }^{9}$ Boat adrift with two dozen African migrants rescued off Brazilian coast: https://www.reuters.com/article/us-migrants-brazil/boat-adrift-with-two-dozen-african-migrants-rescued-off -brazil-coast-idUSKCN1IM01C (accessed May 21 2018).

Acknowledgments

Not applicable.

\section{Funding}

The research presented in this article was built on the authors PhD research that was funded by the Danish Council for Independent Research, Humanities, that supported the collaborative research project 'New Geographies of Hope and Despair' led by Senior Researcher Nauja Kleist from the Danish Institute of International Studies. The funding body shad no role in the research projects design, data collection and analysis.

\section{Availability of data and materials}

Data sharing is not applicable to this article as no datasets were generated or analysed during the current study.

\section{Author's contributions}

This is a singled authored article. The author read and approved the final manuscript.

\section{Author's information}

Ida Marie Savio Vammen is Post-Doctoral Researcher affiliated with the research project: Border Work. An Ethnographic Study of Migrants, Brokers, and European Border Governance in West Africa, at the Danish Institute of International Studies. Her doctoral research at the Department of Anthropology, University of Copenhagen, explored the lives and mobility practices of Senegalese men and women who seek new terrains for social becoming in Buenos Aires, Argentina. Her research interest includes: the multi-scalar politics of mobility that shape international migration today and the everyday lives of migrants and non-migrants, resistance and endurance, transnational family and gender dynamics and religion in the migration process. She has conducted ethnographic fieldwork in Argentina, Senegal, Denmark and Turkey.

\section{Competing interests}

The author declares that she has no competing interests.

\section{Publisher's Note}

Springer Nature remains neutral with regard to jurisdictional claims in published maps and institutional affiliations.

Received: 30 August 2018 Accepted: 26 December 2018

Published online: 22 March 2019

References

Andersson, R. (2014). Ilegality, Inc. Clandestine Migration and the Business of Bordering Europe. Berkeley: University of California Press.

Balibar, É. (2002). Politics and the other scene, Phronesis. London: Verso.

Bauman, Z. (2004). Wasted lives: Modernity and its outcasts. Oxford: Polity Press.

Bertoncello, B., \& Bredeloup, S. (2009). Chine-Afrique ou la valse des entrepreneurs-migrants [China-Africa or the dance of migrant entrepreneurs]. Revue Européenne des Migrations Internationales, 25(1), 45-70.

Boehm, D. A. (2012). Intimate Migrations: Gender, Family, and Illegality among Transnational Mexicans. New York/London: New York University Press.

Bredeloup, S. (2013). The figure of the adventurer as an African migrant. Journal of African Cultural Studies, 25(2), 170-182.

Bredeloup, S., \& Pliez, O. (2005). Migrations entre les deux rives du Sahara [Migrations between the two riverbanks of the Sahara]. Autrepart, 4, 3-20.

Casas-Cortes, M., et al. (2015). Riding routes and itinerant Borders: Autonomy of migration and border externalization. Antipode, 47, 894-914.

Chevalier-Beaumel, G., \& Morales, O. G. (2012). Aproximación etnográfica a la nueva migratión Africana en Argentina: circulación y saberes en el caso de los Senegaleses arribados en las ùltimas dos décadas [Ethnographic approach to the new African migration in Argentina. Movement and knowledge in the case of the Senegalese arrived in last the two decades]. Inicio, 12, 381-405. 
Collyer, M. (2010). Stranded migrants and the fragmented journey. Journal of Refugee Studies, 23(3), 273-293.

Coutin, S. B. (2003). Legalizing Moves: Salvadoran Immigrants' Struggle for U.S. Residency. Ann Arbor, MI: The University of Michigan Press.

Cresswell, T. (2010). Towards a politics of mobility. Environment and Planning D: Society and Space, 28(1), 17-31.

Cresswell, T. (2014). Friction. In P. Adey, D. Bissel, K. Hannam, P. Merriman, \& M. Sheller (Eds.), The Routledge handbook of Mobilities, (pp. 107-116). London: Routledge.

De Clerck, H. (2015). Europe is no longer the only "El Dorado" for sub-Saharan Africans: The case of contemporary Senegalese migration to Turkey. Migration and Development, 4(2), 272-290.

De Genova, N. (2002). Migrant "illegality" and deportability in everyday life. Annual Review of Anthropology, 31, 419-447.

Flahaux, M., \& de Haas, H. (2016). African migration: Trends, patterns, drivers. Comparative Migration Studies, 4. https://doi.org/ 10.1186/s40878-015-0015-6.

Freier, L.F. (2012, May). Crossing the Atlantic in search of new destinations: the motivations of contemporary African migrants to Latin America. The case of Ecuador. Paper presented at the Congress of the Latin American Studies Association, San Francisco.

Freier, L. F. (2013). Open Doors (For Almost All): Visa Policies and Ethnic Selectivity in Ecuador (Working Paper No. 188). San Diego: Center for Comparative Immigration Studies.

Gammeltoft-Hansen, T., \& Sørensen, N. N. (2013). The Migration Industry and the Commercialization of International Migration. London/New York: Routledge.

Glick Schiller, N., \& Salazar, N. B. (2013). Regimes of mobility across the globe. Journal of Ethnic and Migration Studies, 39(2), 183-200.

Graw, K., \& Schielke, J. S. (2012). The Global Horizon: Expectations of Migration in Africa and the Middle East. Leuven: Leuven University Press.

Grimson, A. (2017). Argentina's Anti-Immigrant About-Face. NACLA Report on the Americas, 49(2), 123-126. https://doi.org/10. 1080/10714839.2017.1331792.

Haugen, H. Ø. (2012). Nigerians in China: A second state of immobility. International Migration, 50(2), 65-80.

Hernández-Carretero, M. (2016). Leaving to belong: migration, transnational connectedness and social becoming. (Doctoral dissertation). University of Oslo.

Jackson, M. (2013). The Wherewithal of Life: Ethics, Migration, and the Question of Well-Being. Berkeley and Los Angles: University of California Press.

Khosravi, S. (2018). Afterword. Experiences and stories along the way. Geoforum. Advance online publication. https://doi.org/ 10.1016/j.geoforum.2018.05.021.

Kleist, N., \& Thorsen, D. (Eds.). (2016). Hope and uncertainty in contemporary African migration. New York/London: Routledge.

Lefebvre, H. (1998). The production of space. Oxford: Blackwell.

Lucht, H. (2012). Darkness before daybreak: African migrants living on the margins in southern Italy today. Berkeley: University of California Press.

Maffia, M. (2010). Una contribución al estudio de la nueva inmigración africana subsahariana en la Argentina [A contribution to the study of the new sub-Saharan African immigration in Argentina]. Cuadernos de Antropología Social, 31, 7-32.

Mainwaring, C., \& Brigden, N. (2016). Beyond the Border: Clandestine Migration Journeys. Geopolitics 21(2) pp. 243-262.

Minvielle, R. (2010, November). Migrations africaines et mondialisation par le bas à Buenos Aires [African migration and globalization from below in Buenos Aires]. Paper presented at the IMI African Migrations Workshop, Dakar, Senegal. Retrieved from https://www.imi-n.org/files/events/minvielle.pdf.

Minvielle, R. (2015). L'Amérique du Sud ou l'émergence d'un nouveau théâtre des migrations africaines [South America or the emergence of a new African migration theater]. Afrique et Développement, 40(1), 19-39.

Nyamnjoh, H. M. (2010). We Get Nothing from Fishing: Fishing for Boat Opportunities Amongst Senegalese Fisher Migrants. Bamenda, East Lansing: Langaa Research and Publishing Common Initiative Group, Michigan State University Press.

Pelican, M., \& Tatah, P. (2009). Migration to the Gulf states and China: Local perspectives from Cameroon. African Diaspora, 2(2), 229-245.

Riccio, B. (2001). From "ethnic group" to "transnational community"? Senegalese migrants' ambivalent experiences and multiple trajectories. Journal of Ethnic and Migration Studies, 27(4), 583-599.

Riccio, B. (2008). West African transnationalisms compared: Ghanaians and Senegalese in Italy. Journal of Ethnic and Migration Studies, 34(2), 217-234

Richter, L. (2016). On the edge of existence: Malian migrants in the Maghreb. Culture Unbound. Journal of Current Cultural Research, 8, 75-87.

Rumford, C. (2008). Introduction: Citizens and Borderwork in Europe. Space and Polity, 12(1), 1-12.

Schans, D. (2012). "Entangled in Tokyo": Exploring diverse pathways of labor market incorporation of African immigrants in Japan. African Diaspora, 5(1), 73-89.

Schapendonk, J., \& Steel, G. (2014). Following migrant trajectories: The $\mathrm{im} / \mathrm{mobility}$ of sub-Saharan Africans en route to the European Union. Annals of the Association of American Geographers, 104(2), 262-270.

Schapendonk J., Van Liempt, I., Schwarz, I., \& Steel, G. (2018). Re-routing migration geographies: Migrants, trajectories and mobility regimes. Geoforum. Advance online publication. https://doi.org/10.1016/j.geoforum.2018.06.007.

Sinatti, G. (2009). Home is where the heart abides: Migration, return and housing in Dakar, Senegal. Open House International, 34(3), 49-56.

Streiff-Fénart, J., \& Kabwe-Segatti, A. W. (2012). The Challenge of the Threshold: Border Closures and Migration Movements in Africa. Lanham, Md: Lexington Books.

Suter, B. (2017). Migration and the formation of transnational economic networks between Africa and Turkey: The socioeconomic establishment of migrants in situ and in mobility. African and Black Diaspora: An International Journal, 10(3), 313-326.

Tsing, A. L. (2005). Friction: An ethnography of global connection. Princeton, NJ: Princeton University Press.

Triulzi, A. \& McKenzie, R. (2013). Long Journeys: African Migrants on the Road. Leiden: Brill.

Vammen, I. M. (2016). Sticking to god: Brokers of hope in Senegalese migration to Argentina. In N. Kleist, \& D. Thorsen (Eds.), Hope and Uncertainty in Contemporary African Migration, (pp. 40-57). London/New York: Routledge. 
Vammen, I. M. (2018). The Madness of Migration. An Ethnographic Account of Senegalese Migrants' Mobility and Lives in Buenos Aires. Copenhagen: Department of Anthropology, University of Copenhagen.

Vaughan-William, N. (2008). Borderwork beyond inside/outside? Frontex, the citizen-detective and the war on terror. Space and Polity, 12(1), 63-79.

Vigh, H. (2009). Wayward migration: On imagined futures and technological voids. Ethnos, 74(1), 91-109.

Xiang, B., \& Lindquist, J. (2014). Migration infrastructure. International Migration Review, 48, 122-148.

Zubrzycki, B. (2009). La migración senegalesa y la diáspora mouride en Argentina [Senegalese migration and the mouride diaspora in Argentina]. Paper presented at the VIII Reunión de Antropología del Mercosur. Buenos Aires.

Zubrzycki, B. (2012). Recent African migration to South America: The case of Senegalese in Argentina. International Journal of Humanities and Social Science, 2(22), 86-94.

Submit your manuscript to a SpringerOpen ${ }^{\circ}$ journal and benefit from:

- Convenient online submission

- Rigorous peer review

- Open access: articles freely available online

- High visibility within the field

- Retaining the copyright to your article

Submit your next manuscript at $\boldsymbol{\nabla}$ springeropen.com 